\title{
COUNTERING THE "PHENOMENOLOGY OF WHITENESS": THE NATION OF ISLAM'S PHENOMENOLOGY OF BLACKNESS
}

\author{
E. ANTHONY MUHAMMAD \\ Georgia Southern University
}

The Nation of Islam (NOI), a Black nationalist organization espousing a heterodox Islamic doctrine, has intrigued the American public since its founding in 1930. Producing notable adherents such as Malcolm X, Muhammad Ali, Louis Farrakhan, Khalid Abdul Muhammad, and Imam Warith Deen Mohammed, the NOI has often been heralded for its recruitment and subsequent moral, physical, and spiritual transformation of "the rejected and despised"; the pimps, prostitutes, criminals, drug addicts, and other downtrodden Blacks. Were it just this record of uplift and transformation, the NOI may be viewed favorably in the eyes of mainstream society. In most circles, however, the NOI has been relegated to the margins of serious consideration.

At the heart of this condemnation and dismissal is the contentious and controversial nature of the NOI's religious and social doctrine. Much of the religiously stylized doctrine, referred to as "The Teachings," is viewed as ahistorical narratives and seemingly farfetched, racially antagonistic myths. Three of the more publicly known and controversial aspects of its doctrine are the depictions of whites as "devils" (Muhammad 1965, 100), Blacks as "God" (NOI 1995, 10), and the organization's endorsement of the geographical separation of Blacks and whites (Muhammad 1965, 226). These assertions, along with the NOI's story of Yacub (the progenitor of the white race), clashes between the NOI and police, the organization's militant and quasi-military posture, and other aspects have resulted in the NOI being cast as a potentially violent organization with a penchant for anti-white hatred and anti-Semitism (Anti-Defamation League).

But are myths and an allegedly hate-filled doctrine truly all there is to the NOI? In the words that follow, I offer an analysis of the NOI that counters the traditional indictments referenced above. In doing so, I argue that the polarizing pronouncements and positions of the NOI are more than just the nonsensical rantings of a hate group. Rather, the seemingly divisive theological and separatist rhetoric of the NOI expresses a liberatory doctrine that interprets, in religious terms, the lived experiences of Black people as they navigate an all-encompassing world of white supremacy. Thus, I argue, the pronouncements of the 
NOI work to reclaim and restructure an existence and identity that has historically been negated for Black people. To support my claim, in the second section of this article, I suggest that the NOI's doctrine should be included within the traditions known as Black existential philosophy and Africana phenomenology. I further argue that the NOI uses the phenomenological framework of embodiment to traverse these two traditions.

In the final section of this article, I analyze the purpose and function of three declarations found in the NOI's doctrine: the claims that the white man is the "devil" and the Black man is "God," and that the NOI's goal is establishing a separate, autonomous territory for Blacks. ${ }^{1}$ By destabilizing racially dehumanizing metanarratives and reconstructing the agency of Black existence (mental, physical, and spiritual), it is my argument that the doctrine and practices of the NOI can best be characterized as a restorative and recuperative display of a critical hermeneutic phenomenology, or what I consider a phenomenology of Blackness.

I should, however, be clear that this effort should in no way be viewed as an attempt at validation. My aim is not to "legitimize" The Teachings of the NOI by invoking mainstream philosophies, theories, and scholars. The organization's ninety-year record of the mental, physical, and spiritual transformation of its members and their communities has already conferred legitimacy on the organization in the eyes of many. Rather, I have three goals for this paper. Generally speaking, a major goal is to contribute to the increasing body of scholarly literature that engages in the academic analysis of the NOI. ${ }^{2}$ Scholars in the burgeoning field of Elijah Muhammad Studies attempt to highlight the multifaceted, interdisciplinary nature of the Teachings of the Nation of Islam (Pitre 2010). This analysis is just such an endeavor. As a phenomenologist, another prominent goal of this paper is to provoke in the reader a phenomenological reduction. By moving the reader away from the natural attitude (the every day, "taken for granted" view of the NOI as a violent hate group) to the phenomenological attitude (a suspension of our taken for granted view and an openness to a deeper understanding of the NOI), this paper can hopefully bracket preexisting assumptions about the NOI and offer an altogether different understanding of the organization, its doctrine, and its motives. Building on the previous two goals, the primary goal of this analysis is to retrieve the doctrine of the NOI, commonly referred to as The Teachings, from the dustbin of absurdities to which they have for some time been relegated. This will be done by showing the congruence of the NOI's philosophy with many foundational and widely accepted theorists and philosophies, many of which the NOI predates. I will also show that the NOI's doctrine can also be understood as a creative and potent contribution to a longstanding Black philosophical tradition. By linking the Teachings, philosophy, and phenomenology, my analysis will make clear that, rejecting the NOI's philosophy means simultaneously rejecting many mainstream, highly coveted philosophical traditions. In other words, the aim of this work is vindication, not validation.

\footnotetext{
${ }^{1}$ Here "Black man" is used in the general sense, encompassing both Black men and women.

${ }^{2}$ See Acevedo, Ordner, and Thomspon (2010); Akom (2003); Berg (2005); Curtis IV (2002, 2005); Finley (2017); Gibson and Berg (2017).
} 


\section{A BRIEF HISTORY OF THE NATION OF ISLAM}

Founded on July 4, 1930 by an enigmatic figure named W. D. Fard, the NOI preaches a doctrine of moral uprightness, religious devotion, economic independence, selfdetermination, and a racialized, esoteric version of Islam that was seen as a drastic departure from Islam as preached and practiced throughout the orthodox Muslim world. Erdmann Beynon, in what is likely the earliest scholarly investigation of the organization, noted that the NOI arose "out of the growing disillusionment and race consciousness of recent Negro migrants to northern industrial cities" $(1938,894)$. Fard was said to have come to America from "the Holy city Mecca, Arabia." Upon arrival, he initially went door to door in the poor Black neighborhoods of Detroit, Michigan in an effort to teach the residents "the knowledge of ourselves, of God and the devil" (Muhammad 1965, 16). We are told that Fard

... rapidly gained followers and he continued to teach them about the deceptive character and temporary domination of "blue-eyeddevils" or white man, the glorious history and significance of the "Black Nation," the Caucasian race, the religions of Islam and Christianity and, as well, the "truth" about the beginning of creation. (Tinaz 2001, 15)

From its inception, the doctrine of the NOI has been controversial, polarizing, and racialized. As Beynon documented in 1938, Fard himself authored ritualized texts that taught that

... [t $]$ he Black men in North America are not Negroes, but members of the lost tribe of Shebazz, stolen by traders from the Holy City of Mecca 379 years ago. The prophet came to America to find and to bring back to life his long lost brethren, from whom the Caucasians had taken away their language, their nation and their religion. Here in America they were living other than themselves. They must learn that they are the original people, noblest of the nations of the earth. The Caucasians are the colored people, since they have lost their original color. The original people must regain their religion, which is Islam, their language, which is Arabic, and their culture, which is astronomy and higher mathematics, especially calculus. (900-01)

After three and a half years of proselytizing and amassing a following of five thousand to eight thousand Black adherents in Detroit, Fard vanished in 1934 as abruptly and as mysteriously as he appeared (896-97). Before Fard's departure, he bequeathed leadership of the NOI to Elijah Muhammad, one of his most ardent followers. After assuming leadership of the NOI, Elijah Muhammad began professing that Fard (now referred to as Master Fard Muhammad) was in reality Allah/God in physical form (Gardell 1996, 58). This controversial, anthropomorphic doctrine continues to be the bedrock of the NOI's teaching. 
From the 1930's through the mid-1950's the NOI witnessed moderate growth as Elijah Muhammad spearheaded the founding of temples in various cities including Chicago, Illinois; Milwaukee, Wisconsin; Washington, DC; and Cincinnati, Ohio (Gardell 1996, 65). After experiencing internal strife and waning membership due to Elijah Muhammad's incarceration for violation of the Selective Service Act of 1940, the NOI garnered an explosion in nationwide visibility throughout the 1960's due to the popularity of two of its most captivating and charismatic members, Malcolm X and Muhammad Ali (70-71).

Up through the mid-1970's the NOI witnessed substantial popularity and growth within Black communities nationwide. This growth culminated in the establishment of their own bank, supermarkets, import business, restaurants, bakeries, trucking fleet, printing press, office buildings, slaughterhouses, and other acquisitions that enabled self-sufficiency and independence within the Black community (Muhammad's Temple No. 2 1975). In 1975, however, the NOI would suffer a debilitating loss due to the passing of Elijah Muhammad. Upon his passing, Muhammad's son Wallace assumed leadership of the organization. After assuming leadership, Wallace sold off the assets, properties, and holdings of the organization, changed the name from the NOI to the American Bilallian Community, changed the doctrine to conform with the Islam of the orthodox Muslim world, and renounced all of the racialized, separatist teachings of the NOI (Lincoln 1994, 264-65). This drastic change of course caused several defections from the organization in the months that followed. The most consequential was Minister Louis Farrakhan who, breaking with Wallace's (who had changed his name to Imam Warith Deen Mohammed) new direction in 1977, reconstituted Elijah Muhammad's version of the organization complete with a reinstatement of the name Nation of Islam, the strict codes of behavior, the deification of Master Fard Muhammad, and the original racialized, separatist doctrine (Gardell 1996, 122-35).

The common thread throughout all of the NOI's history, however, has been the considerable condemnation and ire that its teachings have garnered. The Southern Poverty Law Center, an organization itself plagued by charges of systemic racism and sexism, has dismissed the NOI as a "hate group" that espouses a blatantly racist and bigoted doctrine against whites in general and Jews specifically (Valencia 2019; Southern Poverty Law Center). One such example is the charge of anti-Semitism which, to some, is viewed as a normative aspect of the NOI's discourse, doctrine, and practice. But this claim begs the question: normative to whom? Anti-Semitism was certainly not viewed as a defining normative aspect of the NOI by the multitude of black men who attended the Million Man March in 1995. In any case, the charges of anti-Semitism are relatively new (they date to the 1980s) and the focus of the accusations are comments made by the organization's leader (Minister Louis Farrakhan) and not the organization's doctrine itself. It is the organization's doctrine that is the focus of this article.

Although this article does not focus on the claim of anti-Semitism as a normative context in which to view the NOI, this in no way precludes the possibility of discussing other doctrinal aspects that are widely accepted as being normative to the organization. For example, the NOI doctrine on UFOs, the organization's dietary habits (particularly the abstention from eating pork and the group's traditional bean pie dessert), the NOI's visual presentation and aesthetic (the flowing gowns of female members and the signature suit 
and bow tie "uniform" worn by male members), and the group's embrace of patriarchy are all significant and commonly acknowledged normative contexts in which to discuss the NOI. Relatedly, the three controversial tenets of the NOI's doctrine under investigation in this analysis were selected not just for their polarizing nature, but also because of their normativity with respect to the organization's discourse. The three doctrinal aspects under investigation are the pronouncements that the white man is "The Devil" (Muhammad 1965, 100) and the Black man is "God" (NOI 1995, 10), and the NOI's official endorsement of the geographical separation of Blacks and Whites (Muhammad 1965, 226-32). Before dealing at length with these assertions, however, a philosophical grounding must be laid in order to properly contextualize these unsettling claims.

\section{CONTEXTUALIZING THE NOI: PHILOSOPHY, PHENOMENOLOGY, AND EMBODIMENT}

My intent in this section is to view the NOI's doctrine through the lens of two rich traditions, Black existential philosophy and Africana phenomenology. I further argue that it is the NOI's use of the equivalent of the phenomenological concept of embodiment that nestles the group comfortably within the fertile soil of these two philosophical traditions. By viewing the NOI's doctrine through a phenomenological lens, I will be countering the prevailing depictions of the organization. These widely accepted depictions have consistently characterized the NOI's doctrine as "confused and inconsistent" (Lincoln 1994, 79) or as "absurdity" (Clegg 1997, 41). Traditional depictions of the NOI have also framed its members as "ignorant Southern-type Negroes who don't know any better" (Lincoln 1994, 79), have described its patriarch, Elijah Muhammad, as "an illiterate crackpot" (79), and have generally discarded the NOI's entire body of discourse as "fantastic and unbelievable" (xi). Locating the teachings of the NOI within Black existential philosophy and Africana phenomenology neutralizes these superficial, pejorative, and dismissive critiques and at the same time rightly situates the NOI's doctrine within the long-standing tradition of Black philosophical critique. In explicating the deeper philosophical implications of the NOI's doctrine, I will also be confirming Lincoln's assertion that "[a]n ideology, though weird, often means more than it says" (xi).

\section{BLACK EXISTENTIAL PHILOSOPHY}

Black existential philosophy is a philosophy of existence that concerns itself with the "freedom, anguish, responsibility, embodied agency, sociality, and liberation" of Black people (Gordon 1997, 3). Undergirding much of Black existential philosophy is the rejection of normative 
philosophical assertions grounded in western, Eurocentric premises. ${ }^{3}$ A more relevant and localized conception of the world is put forth that "situates philosophical reflective thought within the concrete muck and mire of raced embodied existence" (Yancy 201 1, 552). Thus, there is a rejection and a reflection inherent in Black existential philosophy that asks and answers the question, "[w] hat is to be understood by Black suffering?" (Gordon 1997, 1). Viewed from this vantage point, contributions to Black existential thought span centuries and have been offered by a multitude of writers and theorists such as Frederick Douglas, David Walker, Marcus Garvey, Ida B. Wells, Richard Wright, Alain Locke, Aimé Césaire, bell hooks, and James Baldwin, among countless others. Similarly, the philosophical foundation of the NOI's doctrine is one "born of struggle" (Harris 1983, ix). Framed in this way, the NOI's exegesis fits squarely within the enduring tradition of Black existential thought that seeks the freedom of Black agency through liberation from an anguished Black existence in anti-Black social spaces. This is discussed in more detail in the sections ahead.

On Black suffering, Charles Mills writes that a racialized, embodied existence has the effect of fashioning Black bodies into a racial subperson, meaning "an entity which, because of phenotype, seems ... human in some respects but not in others" $(1998,6)$. Alternatively, Thomas F. Slaughter's articulation refers to racialized embodied existence as "physiognomic degradation" (1983, 284) For Slaughter, degradation based on Black skin first asserts that "Blackness embodies the ostracized" (284). Then, the duress that naturally accompanies the degradation of ostracization produces a "two-pronged process of externally imposed inferiorization and subsequent internalization of that inferiority" (284). Regarding the interrelation between Black existential philosophy and Africana phenomenology, Slaughter's articulation of the epidermalized existence of Black bodies and his conception of the dual inferiorization/internalization process builds upon the ideas of W.E.B. Du Bois and Frantz Fanon, two prominent contributors to Black existential philosophy whose writings vividly charted the landscape of the Black phenomenological experience.

\section{AFRICANA PHENOMENOLOGY}

Paget Henry defined Africana phenomenology as "the self-reflective descriptions of the constituting activities of the consciousness of Africana peoples, after the natural attitudes of Africana egos have been displaced by de-centering techniques practiced in these cultures" (2005, 79). In discussing Africana phenomenology, Henry ascribed its motives as being similar to the rejection and reflection inherent in Black existential philosophy (of which Africana phenomenology is a subfield). Highlighting exemplars of Africana phenomenology, Henry identified Du Bois's phenomenological project and featured it prominently in his discussion. It was in Du Bois's phenomenological description of being a Black man in the

3 Similar if not interchangeable designations are African-American philosophy, Afro-American philosophy, and Africana philosophy. 
U.S. at the turn of the past century that we find one of the most fruitful instantiations of Africana thought.

In Du Bois's phenomenology, for example, we find one of the earliest attempts to carve out a Black consciousness separate and distinct from the universalizations of traditional western philosophy. Specifically, Du Bois's rejection and reconceptualization of Hegel's philosophy gave way to the Du Boisian notions of first site and second site, otherwise known as double consciousness. First site refers to the affirming tendency of a Black person to see one's authentic Black self through one's own eyes, while second site indexes the degrading and debilitating tendency of a Black person "to see him/herself as a 'negro,' that is, through the eyes of the white other" (Henry 2005, 89). For Du Bois, this represented an existential dilemma for Black people that was much different from the one proposed by Hegel. Citing an imperfect fit between the tenets of traditional western philosophy and the Black lived experience, Du Bois's phenomenology establishes "a culturally distinct, and hence nonEuropean, site of original meanings, discourses and experiences" (2005, 85). Emanating from this Black, culturally distinct foundation, the goal of Du Bois's phenomenological project was to enable Africana self-consciousness "to see through the darkness of second sight" (90). In many ways, Du Bois's attempt to rectify Black suffering through reclaiming a proper vision of self was identical to the NOI's goal of counteracting the severe deficiency in Black people's "knowledge of self" (Muhammad 1965, 51) that had been brought on by centuries of degradation at the hands of white society. This was summed up by the NOI in its clarion call, "BLACKMAN, ACCEPT YOUR OWN" (50).

In Fanon's phenomenology, we encounter Black suffering as a result of the penetrating and all-pervasive white gaze. Fanon critiqued Maurice Merleau-Ponty's (and western philosophy's) universalized body schema by fracturing it into thirds. First, a de-centering of Merleau-Ponty's universalized body points out that "the man of color encounters difficulties in elaborating his body schema" because, rather than the certainty of white, habitual actions, what reigns around the Black body is "an atmosphere of certain uncertainty" (Fanon 2008, 90). In this critique of a universal, autonomous body schema, Fanon lays bare the fundamental oversight inherent in Merleau-Ponty, the reality that the Black body inhabiting white spaces has no genuine presence in the white world. The fracturing continues when Fanon invokes the historical-racial schema. The white gaze's stultifying effect on the Black body informs the historical-racial schema by replacing the Black body schema with a caricature of a person that the white psyche has woven "out of a thousand details, anecdotes, and stories" from a contrived Black past (91). The third fracture Fanon introduces is the epidermal-racial schema that synonymizes Blackness with all of the "cannibalism, backwardness, fetishism, racial stigmas" and "slave traders" the white psyche has historically attached to the Black body (92). Ultimately, Fanon's tripartite phenomenology speaks to the negating of the ontological reality of Black bodies. As a result of this negation, a Black ontology "is made impossible in a colonized and acculturated society" (89). Fanon, in his rejection of the white gaze, ultimately arrives at a remedy for this negation, a remedy not unlike what permeates the NOI's pro-Black discourse. That remedy was Fanon's decision "to assert myself as a BLACK MAN" (95). 
Both the broad expanse of Black existential philosophy and its subgenre, Africana phenomenology, are the logical ground in which to frame the NOI's doctrine. Black existential philosophy and Africana phenomenology are rooted in rejection, reflection, and re-articulation. So too is the NOI's philosophy. In the NOI we see a stern rejection, a rebuke even, of traditional, white narratives and depictions of Black bodies. The NOI's hermeneutic reflections on the Black lived experience indict the white psyche and its white supremacist manifestations. In the upcoming discussion, I argue that the NOI's prescriptive measures seek to rehabilitate Black bodies through an emphatic embrace and a bold rearticulation of Blackness. On these grounds, I make the case that the NOI's doctrine is yet another articulation of Black existential philosophy. Instrumental in this articulation is the use of embodiment as the source and the site of their discursive project.

\section{EMBODIMENT}

An integral aspect of philosophical and phenomenological thinking is a concern with the physical body. Our bodies are that which mediate our interaction with and experience of the world. Traditionally, discussions of body have been guided by the Cartesian split that separates mind and body. From this duality, the body is conceptualized as being governed solely by either the physical laws germane to all living organisms (physiological), or a self-constructed, psychological consciousness. In offering a reevaluation of this dualism in phenomenological terms, Merleau-Ponty argued instead for an understanding of the body as that which is produced when the physiological and the psychological "gear into each other" (2012, 79). Describing the intertwined, synergistic nature of the body and the world, Merleau-Ponty metaphorically envisioned "[o]ne's own body in the world just as the heart is in the organism: it continuously breathes life into the visible spectacle, animates it and nourishes it from within, and forms a system with it" (209). Further elucidating his "body schema," Merleau-Ponty notes:

Bodily existence, which streams forth through me without my complicity, is but the sketch of a genuine presence in the world. But it, at the very least, grounds the possibility of such a presence and establishes our primary pact with the world. (168)

Here we see the vital importance of embodiment for Merleau-Ponty. The phrasing "without complicity" speaks to the effortless nature of bodily existence and his mention of "genuine presence" and "primary pact" reflect the preeminence of the body as we experience the world. Understood in this way, embodiment is the very vehicle through which Erlebnis, or our lived experience, is achieved and, according to Merleau-Ponty, universally experienced. However, Merleau-Ponty's universal body schema was rearticulated by Fanon in light of the "disorientation" experienced by Black bodies. 


\section{III.THE DISORIENTED BLACK BODY}

In describing his experience of disorientation, Fanon shares with us that,

Disoriented, incapable of confronting the Other, the white man, who had no scruples about imprisoning me, I transported myself... far, very far from my self, and gave myself up as an object...Yet this reconsideration of myself, this thematization, was not my idea. $(2008,92)$

Further elaborating on the stifling and negating nature of the Black experience under the white gaze, Sarah Ahmed extends Fanon's discussion of disorientation. The crux of Ahmed's argument is that, far from a neutral world of existence that all embodied souls inhabit and experience with equal agency, the world is in fact a racialized one. This racialized world has been constructed so that white bodies experience the world as a "body-at-home" and Black bodies are "stopped" from naturally and effortlessly inhabiting the same world (Ahmed 2006, 111, 110). Regarding this "stopping," Ahmed notes that,

For bodies that are not extended by the skin of the social, bodily movement is not so easy. Such bodies are stopped, where the stopping is an action that creates its own impressions. Who are you? Why are you here? What are you doing? Each question, when asked, is a kind of stopping device: you are stopped by being asked the question, just as asking the question requires you to be stopped. A phenomenology of "being stopped" might take us in a different direction than one that begins with motility, with a body that "can do" by flowing into space. (139)

For Ahmed, the affirming orientation of the world "around" white bodies is in stark contrast to the negating and stultifying orientation of the world "toward" Black bodies (115). This racialized lived experience manifests as a "phenomenology of whiteness" (138) that invites white bodies into a world of "I can" and excludes Black bodies in a disorienting world of "I cannot" (139). To summarize, Ahmed described this racialized phenomenology of whiteness as

... the ease with which the white body extends itself in the world through how it is orientated toward objects and others. To make this point simply: whiteness becomes a social and bodily orientation given that some bodies will be more at home in a world that is oriented around whiteness. If we began instead with disorientation ... then the descriptions we offer will be quite different. (138)

It is my contention that, in the doctrines of the NOI, we encounter a philosophy that does indeed "begin with disorientation." By anchoring their doctrine in the disorienting experiences of Black bodies in white spaces, the NOI has in fact crafted a phenomenology that has proved to be "quite different." The following discussion of three aspects of the 
organization's doctrine introduces what I term the NOI's phenomenology of Blackness. Their phenomenology of Blackness, contrary to the "phenomenology of whiteness" described by Ahmed, is grounded in and privileges the embodied experiences of Blacks. Aspects of the doctrine under analysis in this article are, 1) the assertion that the white man is the "devil," 2) the assertion that the Black man is "God," and 3) the NOI's endorsement of the geographical separation of Blacks and whites. By analyzing each of these assertions in detail, I further argue that the NOI's discursive project, in total, is actually a critical hermeneutic phenomenology presented through the lens and language of religion.

\section{THE NATION OF ISLAM'S PHENOMENOLOGY OF BLACKNESS}

\section{THE WHITE MAN IS THE DEVIL}

Throughout the NOI's discourse and doctrine, whites are frequently referred to as devils. For example, in Message to the Blackman, one of the organization's foundational texts, a chapter entitled "The Devil" offers the official NOI history of and position on the devil. In it, Elijah Muhammad tells us that whites are "a race whom Allah has made manifest to you and me as being real devils" $(1965,100)$. In The Supreme Wisdom, a collection of catechisms, mathematical word problems, and narratives given to Elijah Muhammad by Master Fard Muhammad, we read another descriptive analysis identifying whites as devils. In the "Student Enrollment" the question is asked, "Who is the Colored man?" (NOI 1995, 9). In response, the answer is given: "The Colored man is the Caucasian (white man). Or, Yacub's grafted Devil - the Skunk of the planet Earth" (NOI 1995, 10). In both of these characterizations we find evocative depictions of whites. But what are these assertions if not ad hominem, racially antagonistic attacks?

In a groundbreaking analysis of this aspect of NOI doctrine, Stephen C. Finley situated these "whites as devils" statements within the historical context from which the NOI emerges. He informs us that the notion of the white man being the devil

... is only one small aspect of the narrative that attempts to make sense of an absurd world: a terrifying world for African Americans, in which their bodies were the objects of racial discourses of inferiority and inhumanity that justified their imminent expurgation, destruction, and mutilation for centuries of American history. (2017, 154)

In his analysis, Finley (2017) labels the NOI's summation that white people are devils as "theological phenomenology" and correctly identifies the purpose of this particular claim as describing and interpreting, phenomenologically, the racialized, terrorized existence of Black bodies under white supremacy (157). What Finley goes on to make abundantly clear is that the NOI is first and foremost a religious organization. As such, this realization should 
come to bear on any interpretation or analysis of the claims made by the group. Given this religious core and

[h] aving lived in a world wherein whites would viciously and gratuitously participate in violent and degrading acts against Black people, Muhammad needed a way to make sense of this terror. That is, he needed a theodicy, a way to justify the presence of evil in light of the purported goodness and omnipotence of God. (166)

Through Finley's analysis, one comes to see the summation of whites as devils as a rhetorical device that is not only descriptive of the Black lived experience, but acts also as a theodicy used to make sense of that experience in the minds of oppressed and subjugated Blacks. Viewed in this way, the evocative nature of framing whites as devils sheds light on another of its important functions: its illumination of the fundamental, phenomenological essence of the Black lived experience.

In Researching Lived Experience, Van Manen (2016) wrote that essence

may be understood as a linguistic construction, a description of a phenomenon. A good description that constitutes the essences of something is construed so that the structure of a lived experience is revealed to us in such a fashion that we are now able to grasp the nature and significance of this experience in a hitherto unseen way. When a phenomenologist asks for the essence of a phenomenon-a lived experience - then the phenomenological inquiry is not unlike an artistic endeavor, a creative attempt to somehow capture a certain phenomenon of life in a linguistic description that is both holistic and analytical, evocative and precise, unique and universal, powerful and sensitive. So an appropriate topic for phenomenological inquiry is determined by the questioning of the essential nature of a lived experience: a certain way of being in the world. (39)

Van Manen's description captures the "essence" of what is at work in the NOI's "linguistic construction" of whites as devils. The construction itself is an attempt to "describe the phenomenon" of the Black experience under entrenched and institutionalized white supremacy. The racialized language (which matches the violent and viciously racialized nature of white supremacy) grabs our attention in such a way that we easily "grasp the nature and significance" of what it is like living as a Black body in a viciously racist society. By framing Black embodiment in this way, the NOI is giving a "good description" of Black lived experiences in a "hitherto unseen way." By enlisting creatively descriptive religious symbolism (framing whites as "devils"), these linguistic framings are "not unlike an artistic endeavor." By likening the day to day experiences of segregation, lynching, rape, murder, police brutality, and the deprivation of humanity and justice as the equivalent of "Hell," the NOI's reference to whites as "devils" identifies them as the authors and overlords of this Hellish Black existence just as the devil, in theology, rules as the overlord of Hell. In this way, this linguistic framing of Black existence serves as an "attempt to somehow capture 
a certain phenomenon of life in a linguistic description that is both holistic and analytical, evocative and precise, unique and universal, powerful and sensitive" (Van Manen 2016, 39). In short, declaring that white people are devils uses religious language to offer a creatively descriptive way of tapping into the essence of Black life under white supremacy. By doing so, the NOI is offering a disruptive portrayal of "a certain way of being in the world," that is, being Black in a world of white, terroristic spaces.

\section{THE BLACK MAN IS GOD}

While proclaiming that white people are "The Devil" is, as we have seen, both descriptive and creatively interpretive, its corollary, the Black man is "God", serves a different purpose. Referring back to the "Student Enrollment" in the NOI's Supreme Wisdom, we are asked, "Who is the Original man?" (NOI 1995, 9). In response we are told, "The Original man is the Asiatic black man; the Maker; the Owner; the Cream of the planet Earth - God of the Universe" (NOI 1995, 10). By offering these pronouncements on God and the devil, the NOI is in fact linguistically disrupting the "normality" of "habitual" "at home in the world") white existence. By doing so, the NOI displays an understanding of the fact that "the Black body has, within the context of its tortuous sojourn through the crucible of American and European history, been a site of discursive, symbolic, ontological, and existential battle" (Yancy 2017, 106). By deploying a disruptive language that intends to boldly re-orient Black embodiment in the world, the NOI becomes a willful and active combatant in this "existential battle" by engaging in linguistic resistance. But just as casting the white man as "The Devil" is deconstructive in its ability to dismantle the psychological pedestal that whites have constructed and perched themselves upon, proclaiming that the Black man is "God" is constructive, serving to rebuild an affirming, authentic, and agential Black existence that the "phenomenology of whiteness" had destroyed.

Bolstering this point, Yancy informs us that, "Black resistance, as a mode of decoding, is simultaneously a process of recoding Black embodied existence through processes of opposition and affirmation." He further notes that, "the moment of resistance, in other words, is the moment of becoming, of being made anew" (2017, 108). Yancy's idea of "resistance as becoming" is the driving force behind the NOI's statement that the white man is "The Devil" and the Black man is "God." In an effort to repair centuries of mental, physical, psychological, and spiritual abuse at the hands of white society, the NOI deploys a religiouslystyled countermeasure that seeks both to stabilize and destabilize, to build and destroy. For the NOI, the denouncement of whites as "devils" minimizes those who were once deified while the framing of Blacks as "Gods" rehabilitates those who were once dehumanized. Commenting on this type of bi-directional, ontological swing, Yancy tells us that

$[\mathrm{T}]$ here is a moment of renarrating the self at the moment of resistance, which also involves a disruption of the historical force of the white same; for to resist is to re-story one's identity, even if that story is fragmented and replete with tensions. (110) 
But the invocation of "God" status for Blacks intends to do more than just "re-story" the identity of disoriented Blacks in theological terms. While the ontological reality of whites as "The Devil" serves a phenomenologically $d e$-scriptive purpose, conferring godhood on Black bodies is pre-scriptive; it aims to prescribe actions that will ultimately transform the disoriented Black body through a ritualized process of molding righteous words, ways, and actions. I liken this prescriptive strategy to the idea of mimicry as described by MerleauPonty.

In Phenomenology of Perception (2012), Merleau-Ponty describes the "mimicry" involved when he lays down to go to sleep. He notes that, by mimicking the process of sleep (by lying in bed on his side, knees drawn up, breathing slowed and eyes closed), sleep eventually takes over him. Speaking on the process of mimicking sleep in order to induce sleep, MerleauPonty says:

The role of the body is to ensure this metamorphosis. It transforms ideas into things and my mimicry of sleep into actual sleep. If the body can symbolize existence, this is because it actualizes it and because it is its actuality. (167)

The transformation from Blacks as disoriented to Blacks as Gods is where Merleau-Ponty's words coincide with the NOI's doctrine and practice. Within the NOI there exists a strict code of behavior and an expectation of moral thinking, speaking, and living. This has been codified into what is called The Restrictive Law of Islam (Farrakhan 2012, 35). All of the mental, physical, and linguistic activities that one engages in are expected to be carried out in a righteous and morally upstanding manner. This regimented righteousness is akin to Merleau-Ponty's mimicry of sleep. In seeking to transform from a waking state to a sleeping state, Merleau-Ponty adopted the posture, positions, and activities of a sleeping person. Eventually, "[s]leep 'arrives' at a particular moment, it settles upon this imitation of itself that I offered it, and I succeed in becoming what I pretended to be" $(2012,166)$. In this same way, the regimented actions, thoughts, and behaviors of NOI adherents are enacted in their daily lives in order to mimic righteous, godly behavior. By thinking, believing, and acting as though one is God-like, it is presumed that, like Merleau-Ponty's mimicking of sleep, a "metamorphosis" of the Black mind and body will also "arrive," at which time the NOI adherent has succeeded "in becoming what they pretended to be." Thus, understanding the NOI's claim that the Black man is "God" in the context of the mimicry of sleep allows us to rework Merleau-Ponty's quote to state that: The Black man is God. The role of the body is to ensure this metamorphosis. It transforms the NOI's idea that the Black man is God into things and my mimicry of God into actual godhood. If the body can symbolize my existence as God, this is because it actualizes it and because it is its actuality. 


\section{SEPARATION}

The third doctrine under analysis in this article is the promotion of separation as an objective of the NOI. In keeping with its religious tenor, the NOI's call for separation is also grounded in a theological context. According to Elijah Muhammad,

This is the great Day of Separation. We heard of this kind of time coming ever since we were born. Right? Time! What Time? Time for the Great Separation of Black and white. The Bible teaches you that there will come a Great Separation...This is what the Bible means when it says, 'He will separate the goats from the sheep.'... They are talking about the Black Man and the white man. The white man is the goat and you and I are the sheep. (Muhammad quoted in Rassoull 1992, 492)

The call for separation was also publicized in more secular terms. In a section of Elijah Muhammad's Message to the Blackman entitled "What Do The Muslims Want?", the call for separation is again made in unequivocal language $(1965,161)$. In point number four we are told that,

We want our people in America whose parents or grandparents were descendants from slaves to be allowed, to establish a separate state or territory of their own - either on this continent or elsewhere. We believe that our former slave-masters are obligated to provide such land and that the area must be fertile and minerally rich. We believe that our former slave-masters are obligated to maintain and supply our needs in this separate territory for the next 20 or 25 years until we are able to produce and supply our own needs. Since we cannot get along with them in peace and equality after giving them 400 years of our sweat and blood and receiving in return some of the worst treatment human beings have ever experienced, we believe our contributions to this land and the suffering forced upon us by white America justifies our demand for complete separation in a state or territory of our own. (161)

Here Muhammad establishes both a religious and a socio-historical foundation for his call for the establishment of an orienting, habitual, affirming, Black space, separate and distinct from the disorienting, non-habitual, and dehumanizing existence of Black bodies within the white world. The NOI's call for separation is also geo-political in that it is reminiscent of the separation that led to the founding of the nation of Israel in 1948 as well as to the colonial separation from England that led to the establishment of the United States. The religious nature of the call for separation mirrors the Biblical accounts of Moses' separation from Pharaoh, Lot's separation from Sodom and Gomorrah, and the Islamic separation of prophet Muhammad from Mecca resulting in his hegira to Medina. But even though the NOI's call for physical separation is fueled by the daily atrocities experienced under the "phenomenology of whiteness," its specific goal is the ultimate attainment of a Black 
"corporeal schema" (Ahmed 2006, 110).

Ahmed, using Fanon's critique of Merleau-Ponty as a point of departure, observes that the universal and undifferentiated "corporeal schema" that western phenomenology promoted is not the most basic experience. ${ }^{4}$ Below this "tactile" and "vestibular" experience of the world is a historical-racial schema that supersedes it. This was masterfully exemplified through the notion of an "active body" (the white body) as opposed to the Black body that has historically been "negated or 'stopped' in its tracks" (2006, 110). Simple tasks (such as Fanon's grasping of a cigarette across a table for example) are implicit to us because our bodies are oriented in a space and we know that after initiating a few deliberate steps we will achieve a simple task. This orientation and intentionality toward an object or task represents one of the stalwart philosophical foundations of phenomenology, the notion of "habitual" functioning (130). Drawing from Fanon, Ahmed however informs us that deliberateness is not a given when one inhabits a Black body. White society "stops" Black bodies from gaining such a deliberateness and a familiarity with the world through racism, slavery, Jim Crow, stop and frisk, voter id laws, and other discriminatory realities. This stifling of the most basic elements of consciousness and intentionality "interrupts" the way of being in the world for Black bodies; "the disorientation affected by racism diminishes capacities for action" (Ahmed 2006, 111, emphasis added). It is this disorientation that the NOI confronts and seeks to emancipate Black bodies from through its doctrine of separation.

Ahmed goes on to say that, "[i]f to be human is to be white, then to be not white is to inhabit the negative: it is to be 'not'. The pressure of this 'not' is another way of describing the social and existential realities of racism" (2006, 139). The NOI's approach to establishing its own "corporeal schema" is to dis-"inhabit the negative," to depart from this negating existence in white society through physical separation. In their view, given the four hundred-year history of being "not" and the centuries of "historic-racial" "stopping" of Black existence, the only meaningful solution is separation by which Blacks can then be reconstituted in a space of their own and where the Black body can "extend itself...in order to act on and in the world" (139, emphasis added). Said differently, the NOI's doctrine of physical, geographical separation is an attempt to return the Black body to phenomenology's corporeal schema, that of a habitual and delberate existence of a "body at home" and a "Being in place" (111). For the NOI, this can only be accomplished through the establishment of a separate and distinct Black space (territory) removed from the tyranny of white supremacy. The freedom to act on and act in a world of their own through establishing a separate, physical territory is the manifest expression of the NOI's phenomenology of Blackness.

${ }^{4}$ Ahmed is referencing Fanon (2008, 91). 


\section{V.THE NOI'S CRITICAL HERMENEUTIC PHENOMENOLOGICAL DISCOURSE: AN APOLOGIA}

In this article I've offered a picture of the NOI that departs from the traditionally dismissive posture taken toward the organization. Looking past initially polarizing aspects and surface assumptions about its doctrine, I've made the case for the congruence of the NOI's doctrine with longstanding Black and White philosophical traditions. I've further argued for a depiction of the NOI, its doctrine, and its practices as strategic displays of a critical hermeneutic phenomenology. The NOI's doctrine is critical because of its emancipatory and transformative aims. The NOI's doctrine is hermeneutic due to its creative use of religious motifs as interpretive agents of the world around them. And the NOI's doctrine is phenomenological due to its descriptive and interpretive manner of ascribing meaning to the lifeworld of disoriented Blacks. Additionally, utilizing three examples, I have suggested an understanding of the NOI's creed that offers a deeper, richer explanation of the NOI's complex interplay of linguistics, religion, philosophy, and phenomenology that are tied together through the framework of embodiment.

Despite all that I've presented, there may still be lingering questions about the historicity, rationality, and harshness of the NOI's discourse. As for the historicity of the doctrine, some scholarship, particularly the work of religious scholar Dr. Wesley Muhammad, has indeed defended the veracity of the NOI's claims epistemologically by investigating the evidence for the organization's doctrine and the factual nature of its claims (Muhammad 2007; 2009; 2012; 2013). The current study, however, is ontological and, as such, a more pertinent question should focus on the "workable" and "unworkable" nature of the NOI's doctrine (Yancy 2017, 112). In other words, does the NOI's doctrine work? Does it adequately orient disoriented Black bodies and create a reality of "I can" for Black bodies seeking to escape the "I cannot" of white spaces (Ahmed 2006 139)? Regarding the rationality of the NOI's pronouncements, I offer the words of the hermeneutic philosopher Wilhelm Dilthey who proclaimed that, "all understanding contains something irrational because life is irrational" (2006, 162). Given the irrationality of institutionalized, state sanctioned torture, lynching, discrimination, dehumanization, slavery, and other atrocities of the Black experience under white supremacy, one could argue that the presumed irrationality of the NOI doctrine merely reflects the irrationality of the Black lived experience in white spaces. And finally, on the unapologetic boldness of the NOI's language and the brazen, harsh tone that is often taken, I am reminded of the words of Frantz Fanon when he said,

I want my voice to be harsh, I don't want it to be beautiful, I don't want it to be pure, I don't want it to have all dimensions. I want it to be torn through and through, I don't want it to be enticing, for I am speaking of man and his refusal, of the day-to-day rottenness of man, of his dreadful failure. $(1967,49)$ 
The critical hermeneutic phenomenology of the NOI, what I label its phenomenology of Blackness, is harsh because the lifeworld of Black embodiment in white spaces has been and continues to be harsh.

\section{REFERENCES}

Acevedo, Gabriel A., James Ordner, and Miriam Thompson. 2010. "Narrative Inversion as a Tactical Framing Device." Narrative Inquiry 20 (1): 124-52.

Ahmed, Sara. 2006. Queer Phenomenology: Orientations, Objects, Others. Durham, NC: Duke University Press.

Akom, A. A. 2003. "Reexamining Resistance as Oppositional Behavior: The Nation of Islam and the Creation of a Black Achievement Ideology." Sociology of Education 76: $305-25$

Anti-Defamation League. n.d. "The Nation of Islam." https://www.adl.org/resources/ profiles/the-nation-of-islam

Berg, Herbert. 2005. "Mythmaking in the African-American Muslim Context: The Moorish Science Temple, the Nation of Islam, and the American Society of Muslims." Journal of the American Academy of Religion 73 (3): 685-703.

Beynon, Erdmann D. 1938. "The Voodoo Cult Among Negro Migrants in Detroit." The American Fournal of Sociology 4 (6): 894-907.

Clegg III, Claude A. 1997. An Original Man: The Life and Times of Elijah Muhammad. Chapel Hill: The University of North Carolina Press.

Curtis, Edward E. 2002. "Islamizing the Black Body: Ritual and Power in Elijah Muhammad's Nation of Islam." Religion and American Culture: A Journal of Interpretation 12 (2): 167-96.

- 2005. "African-American Islamization Reconsidered: Black History Narratives and Muslim Identity." Fournal of the American Academy of Religion 73 (3): 659-84.

Dilthey, W. 2006. "The Understanding of Other Persons and Their Life-Expressions." In The Hermeneutics Reader: Texts of German Tradition from the Enlightenment to the Present, edited by Kurt Mueller-Vollme, 152-64. New York: Continuum.

Fanon, Frantz. 1967. Toward the African Revolution: Political Essays. Translated by Haakon Chevalier. New York: Grove Press. 
—. 2008. Black Skin White Masks. Translated by Richard Philcox. New York: Grove Press.

Farrakhan, Louis. 2012. The Restrictive Law of Islam is Our Success. Chicago: Nation of Islam National Center for the Re-Education \& Re-Training of the Black Man and Woman of America and the World.

Finley, Stephen C. 2017. "The Secret... of Who the Devil Is: Elijah Muhammad, the Nation of Islam, and Theological Phenomenology." In New Perspectives on the Nation of Islam, edited by Dawn Marie Gibson and Herbert Berg, 154-73. NewYork: Routledge.

Gardell, Mattias. 1996. In the Name of Elijah Muhammad: Louis Farrakhan and the Nation of Islam. Durham, NC: Duke University Press.

Gibson, Dawn Marie and Berg, Herbert, eds. 2017. New Perspectives on the Nation of Islam. New York: Routledge.

Gordon, Lewis R. 1997. "Black Existential Philosophy." In Existence in Black: An Anthology of Black Existential Philosophy, edited by Lewis R. Gordon, 1-9. New York: Routledge.

Harris, Leonard, ed. 1983. Philosophy Born of Struggle: Anthology of Afro-American Philosophy from 1917. Dubuque: Kendall/Hunt Publishing Company.

Henry, Paget. 2005. "Africana Phenomenology: Its Philosophical Implications." The CLR fames fournal 11: 79-112.

Lincoln, C. Eric. 1994. The Black Muslims in America, 3rd edition. Grand Rapids: William B. Eerdmans Publishing Company.

Merleau-Ponty, Maurice. 2012. Phenomenology of Perception. Translated by Donald A. Landes. New York: Routlege.

Mills, Charles W. 1998. Blackness Visible: Essays on Philosophy and Race. Ithaca: Cornell University Press.

Muhammad, Elijah. 1965. Message to the Black Man in America. Chicago: Muhammad's Temple No. 2.

Muhammad, Wesley. 2007. The Book of God: An Encyclopedia of Proof That the Black Man is God. Atlanta: A-Team Publishing.

- 2009. Black Arabia and the African Origin of Islam. Atlanta: A-Team Publishing. 
—. 2012. Egyptian Sacred Science and Islam: A Reappraisal. Atlanta: A-Team Publishing.

- 2013. Religion of the Black God: Indic Sacred Science E Islam. Atlanta: A-Team Publishing.

Charles 67x, ed. Muhammad's Temple No. 2. n.d. "Accomplishments of the Muslims. 1975. Chicago. http://docs.wixstatic.com/ugd/4c64a0_03c83375e8c54454a304db87-c6c3flbb.pdf

Muhammad, Master Fard. 2014. The Supreme Wisdom: Lessons, edited by Suzanne Brawtley. St. Johns, Antigua and Barbuda: Brawtley Press.

Pitre, Abul. 2010. An Introduction to Elijah Muhammad Studies: A New Educational Paradigm. Lanham, MD: University Press of America.

Rassoull, Abass. 1992. The Theology of Time by the Honorable Elijah Muhammad the Messenger of Allah. Hampton, VA: UBUS Communications Systems.

Slaughter, Thomas F. 1983. "Epidermalizing the World: A Basic Mode of Being Black." In Philosophy Born of Struggle: Anthology of Afro-American Philosophy from 1917, edited by Harris Leonard, 283-87. Dubuque: Kendall/Hunt Publishing Company.

Southern Poverty Law Center. n.d. "Nation of Islam.” https://www.splcenter.org/ fighting-hate/extremist-files/group/nation-islam.

Tinaz, Nuri. 2001. "Conversion of African Americans to Islam: A Sociological Analysis of the Nation of Islam and Associated Groups." PhD diss., University of Warwick.

Valencia, N. 2019. "Famous civil rights groups suffers from 'systemic culture of racism and sexism,' staffers say." CNN, March 29. https://www.cnn.com/2019/03/29/ us/splc-leadership-crisis/index.html

Van Manen, Max. 2016. Researching Lived Experience: Human Science for an Action Sensitive Pedagogy. New York: Routledge..

Yancy, George. 2011. "African-American Philosophy: Through the Lens of SocioExistential Struggle." Philosophy and Social Criticism 37 (5): 551-74.

- 2017. Black Bodies, White Gazes: The Continuing Significance of Race in America, 2nd edition. Lanham, MD: Rowman \& Littlefield. 